\title{
Organizational and Managerial Challenges of Reforming Slovenian Public Agencies
}

\author{
Polonca Kovač \\ University of Ljubljana, Faculty of Administration, Gosarjeva ulica 5, SI-1000 Ljubljana, \\ polonca.kovac@fu.uni-lj.si
}

\begin{abstract}
Introduction: Agencies are among the key contemporary public organizations, prospering within reforms carried out worldwide to increase professionalism and rationalism in public administration (PA). Hence, countries have been establishing agencies and delegating them public tasks in order to achieve expertise-based instead of politically-driven and thus more efficient public policies. In such context, the present article addresses the most important strategic documents related to public administration reform (PAR) in Slovenia, analyzing their goals in terms of agencification and the main implementation results and gaps.

Research Design: The research is dedicated to exploring the governmental approach to agencification as a key aspect of PAR. It analyzes (1) the main PAR strategic documents on public agencies in Slovenia since the mid-90s, and (2) the perceived implementation of structural and managerial autonomy as the declared goal of agencification. Combined research methods are applied, including descriptive analysis, regional comparisons, structural interviews among representatives of public agencies and their parent ministries, and selected statistical data analysis.

Results: As proven by different research methods, the hypothesis whereby agencification goals in Slovenia are largely achieved as part of PAR documents in terms of autonomous organizational structure was confirmed. A more elaborated agencification in PAR documents relates to higher implementation of autonomy.

Conclusion: Nevertheless, the professionalism of Slovenian agencies is still an on-going process, particularly as regards the efficiency implementation gap. As for the future, a more consistent PAR incorporating cross-sectoral policy on agencies is required to pursue the development of a democratic and efficient PA.
\end{abstract}

Keywords: public administration reform; agencies; autonomy; organization; management; Slovenia.

\section{Introduction}

Public administration (PA) reforms (PAR) and cross-sectoral restructuring, such as agencification, are highly complex processes. Being interdisciplinary and long-term oriented, politics-in-power dependent, etc., these reforms are generally addressing the PA wicked problems. Their characteristics are even more pronounced in cases where the main goal of reforms seems to be a shift in the governance mode (cf. Pollitt and Bouckaert, 2011: 9, Bevir et al., 2011: 17 and the following).

Owing to significant societal changes, especially in Eastern Europe in the past decades, PA reforms are the never-ending story of contemporary society (cf. Vintar et al., 2013: 154 and the following). The agency model of PA functions is declared as an inevitable part of PAR (also in Eastern Europe, Musa \& Koprić, 2011: 34, Van Thiel, 2011: 16, Verhoest et al., 2012: 414-420). Moreover, managerialism and the agency model of PA are recognized as important theories for (post-) NPM related reforms in general (Boston, 2011: 20). A governance-related debate in PA in this sense was brought to the fore in the mid-1990s, mainly with the debate about hollowing-out of the state (as defined by Pollitt \& Talbot, 2004; Bugarič: 2004: 1394). Consequently, the need for introducing a new reform package in the field was put forward (more in Peters \& Pierre, 2005).

Semi-autonomous and autonomous agencies have a rather long tradition in the region - in fact, they have been present in certain fields for more than 20 years

Received: August 18, 2014; revised: September 12, 2014; accepted; October 11, 2014 
(Koprić et al., 2012/13: 18). According to the typology in comparative terms (see Verhoest et al., 2012: 20-23), Slovenia mainly established what are known as type 1 (executive, mainly semi-autonomous, still structured within ministries) and type 2 (mainly regulatory, organizationally autonomous) agencies. The article focuses on type 2 agencies as they are (or are supposed to be, following the criteria of organizational and managerial autonomy), the "true" independent type of PA forms.

Agencification is indeed an important research area and is further stimulated by the recent development of the theoretical framework of PAR, based on post-New Public Management (NPM) and good governance concepts (see Christensen \& Lægreid, 2011: 391-403, Bevir et al., 2011: 256). Reforms are in fact conducted through networking and open structures rather than authoritatively and from top to bottom (Bevir et al., 2011: 286 and the following). Within the concept of good governance, this approach of the state will eventually lean from authoritative and centralized to a service-oriented and decentralized one, among others by agencification.

Following PA governance theories, starting with NPM, the article is addressing PAR goals and results related to public agencies and the overall agencification process in Slovenia and in the region. The article has several aims since open issues are emerging as a result of the lack of a relevant study on agencification within PAR so far. In other words, the objective of this research is to interlink PAR strategic design with the achieved implementation of organizational and managerial autonomy in public agencies (in Slovenia). The umbrella aim of the article is to introduce the idea of an inevitable need to plan and implement agencification as a cross-sectoral public policy and part of a centrally driven PAR. Otherwise, the declared goals of a more efficient and professional PA will not be reached.

The basic assumption is that a more systematic elaboration of agencification within strategic PAR documents would lead to higher autonomy and professionalism in performing the agencies' public tasks. Moreover, the study aims to identify the key elements of agencies' autonomy as the primary characteristic goal of agencification. Since agencification is not consistently part of PAR in Slovenia, most experts and agencies' managers anticipate that their autonomy will not be fully implemented (yet).

The research questions are primarily addressing structural reorganization and managerial autonomy of the agencies. Together with the corresponding descriptive and empirical methods, they tackle several issues. Firstly: To what extent and in which aspects do the central PAR strategies focus on public agencies? Secondly: Do these goals correspond to the ones acknowledged in theoretical and comparative analyses, namely autonomy and efficiency? Thirdly: What is the level of implementation of organizational and managerial autonomy in Slovenian public agencies compared to PAR goals? The first two questions are addressed by descriptive analysis and comparative studies. The third question is examined within normative and statistical analysis of HR and finances in all Slovenian state public agencies and as an evaluation perceived by interviewees from seven selected agencies and their parent ministries in different fields.

The interviews were conducted in a structured model, addressing theoretically defined aspects of autonomy. The objective indicators from the annual reports of respective agencies were verified by these selected perceptions. Yet, in order for the PAR or any other public policy to be analyzed and run further on the basis of feedback about their hitherto implementation, at least the general and qualitative criteria of evaluation still need to be developed. This article represents an initial attempt in this direction.

\section{Organizational and Managerial PAR on Agencies - Overview}

Worldwide, administrative reforms have been implemented as a process of modernization since the late 1980s. The term "public-administration reform" has been in frequent use in Western European democracies, being closely associated with general attempts at redefining the role and mission of state structures and the quality of governance (more in Pollitt $\&$ Bouckaert, 2004, Eymeri-Douzans \& Pierre, 2011). These reform waves reached Slovenia and the rest of the post-socialist countries in the 1990s along with their respective independence processes, characterized as an attempt to constitute a system resembling the Western societies (in general Dunn et al., 2006; Kovač \& Virant, 2011: 30; Vintar et al., 2013: 156). The PA reform in Eastern Europe was more or less a systematic set of strategies and measures, at least from the mid-1990s to 2013.

Until full membership, PAR in respective countries, also in Slovenia until 2004, was closely related to the aspirations to join the EU. The main differences between CEE and Western European countries are therefore in the timing and variation, but not in the substance of PAR and agencification (Van Thiel, 2011: 15-32). Likewise, similarities between CEE countries appear to be related more to the timing of state reforms and $\mathrm{EU}$ accession requirements than to the communist legacy of these countries.

Agencification is often declared as a crucial part of PAR, striving for increased efficiency and professionalism of PA (OECD, 2004: 15 and the following). Such approach is common worldwide (Peters and Pierre, 2005: 260). Agencies prove to bring more value added to traditional Weberian hierarchy in modern complex society than side effects (Koprić et al., 2012/13: 41).

Slovenia is considered one of the most successful post-socialist states that introduced reforms in its PA soon after gaining independence and has been working intensely on these processes ever since (Vintar et al., 2013: 153). The country indeed underwent deep changes, starting with independence in 1991 and followed by full EU membership in 2004. Recently, the Slovenian administrative system was 
severely affected by the economic crisis. The main focus of the reform in Slovenia was on PA reorganization and its rationalization, with some (later more emphasized) measures to achieve a more user-oriented PA. The delegation of authority from state administration to independent and autonomous agencies was seen as a measure meeting all listed directions of PAR (see Table 1, elements based on Pollitt et al., 2008/09 and Eymeri-Douzans \& Pierre, 2011: 121).

Despite some achievements of Slovenia (alone and regionally, see Kovač \& Virant, 2011: 42, 255 and the following), it is not surprising that the export of Western practices, agencification process included, led to a significant implementation gap. Agencification and PAR in general often met with a number of politically and managerially conditioned difficulties. The same applies for agencies, while Slovenian strategies and results mostly resemble the Eastern European pattern. Here, comparative studies on agencification distinguish two groups, namely CEE countries and SEE countries, differing in terms of number and especially level of type 2 agencies' autonomy (see Verhoest et al., 2012: 23, UNAID, 2013: 25, but none of Eastern European countries included in Christensen \& Lægreid, 2011). In this context, PAR and agencification are more about "window dressing" than about an internally driven transformation of PA toward NPM and good governance modes.

As explored by Pollitt \& Bouckaert (2011, cf. Randma-Liiv, 2008) on public management reform, there are two main PA and PM reform approaches or models. First, there is what is known as traditional or classical Weberian model, with agencies as mostly internal form of coherent and hierarchical PA. Second, there is the Neo-Weberian State, upgrading the first model and (post-) NPM doctrine, characterized by four dimensions. These items all reflect (see Table 1) one or more key PAR goals or results in relation to the functioning of (public, autonomous) agencies. With focus on the main research issue, namely agencies' autonomy, one can identify the following elements of agencification within Neo-Weberianism. First, by re-shifting agencies, their tasks and resources to indirect PA, prior internal rules orientation is transformed into an external, citizen-oriented focus and post control. Second, by means of professionalism, agencies gain expertise-driven legitimacy, which replaces direct representative democracy. Hence, there is a shift from a classical 'bureaucrat' to a professional manager who is oriented to meet the needs of the citizen.

Similarly to other countries in the region, Slovenia carried out its PA reform in several steps. Firstly, there was the path of revolution (1990-1994), further transition (19951997) and EU accession and integration (1996-2004). Afterwards, continuous modernization was developed through specific policies (2003-2008). Finally, adjustments to cope with the economic crisis were made (2008-2014). Likewise, also PA development in general (beyond Slovenia) consisted of several phases (according to Lane, 1995): (1) transformation (i.e. establishment of a new, democratic political system with several political parties, regular elections, local self-government, etc.); (2) consolidation (i.e. stabilization of political system, new opportunities for privatization, denationalization, and implementation of free market elements); (3) modernization (i.e. reform of public institutions,

Table 1: Slovenian PAR (Neo) Weberian and NPM focuses - agencification relevance (source: based on Pollitt et al., 2008/09, and Pollitt \& Bouckaert, 2011)

\begin{tabular}{|c|c|c|}
\hline $\begin{array}{c}\text { Core claim elements of Neo-Weberianism } \\
\text { in Slovenia }\end{array}$ & $\begin{array}{c}\text { General PAR } \\
\text { orientation } \\
\text { 1996-2014 }\end{array}$ & $\begin{array}{c}\text { Relevance } \\
\text { to public } \\
\text { agencies }\end{array}$ \\
\hline Classical PA “Weberian" elements & & \\
\hline State as the main facilitator of society & Medium & High \\
\hline The role of representative democracy & Medium \\
\hline Basic principles of administrative law & High & Medium \\
\hline A public service with a distinctive status & Medium & \\
\hline “Neo-Weberian" \& post-NPM \& \\
good governance elements & & \\
\hline External orientation towards citizens & High & High \\
\hline Rationalization with post control & High & High \\
\hline Professionalism of public service & High & High \\
\hline
\end{tabular}


their reorganization and gradual deregulation); and (4) adaptation (i.e. establishing efficiency and effectiveness of the state and its regulation). In Slovenia, just like in comparable countries, two main processes can be identified in the PAR context: (1) modernization in terms of political interests and in substantive and technical terms, i.e. informatization, and (2) Europeanization, both during accession to the EU and as a member thereof (Vintar et al., 2013: 159, cf. Pollitt et al., 2008/09: 56). Agencification would fit no earlier than within Lane's (1995) phases of modernization and adaptation (3 and 4) and within both main PAR processes: modernization and Europeanization.

However, most strategic documents (cf. Government, 1996, 2003, 2011, 2012, see Table 3) merely refer to the adoption of new law(s) rather than to overall field transformation which would also involve a change of culture (as opposed to only structural elements). The mid-term strategy "on further development of the public sector" (adopted in July 2003) and, particularly, Slovenia's Development Strategy (2005-2013) and the Exit Strategy (from economic crisis, 2010) underlined the importance of a coordinated approach to modernization. Any reform would be evaluated as to the goals pursued, which is either to maintain (what is functioning well), modernize (i.e. harmonize the operations with broadly accepted concepts and standards), marketize (bring PA closer to the principles and operations of the private sector), or minimize the public share (Pollitt \& Bouckaert, 2004: 39-64). The Slovenian administrative reforms can thus be categorized under several targets. On one hand, there is the obvious goal of rationalization and wish for greater efficiency (minimization), while on the other a confirmation of the existing regulation (maintenance) is detected. Both dimensions together constitute the omnipresent Slovenian PA modernization processes.

Agencies, especially independent regulators, have certain typical advantages but also raise some concerns, as stated by several scholars and comparative studies (such as Kovač \& Virant, 2011: 70 and the following, Verhoest et al., 19 and the following). The delivery of public tasks can become more efficient because they are specialized, oriented to specific areas or sectors and able to engage specific expertise. They can be more devoted to their missions and to general public interest because they do not have to take into consideration wider, i.e. political circumstances. On the other hand, there are concerns as to their accountability, transparency and technocratic risks. As regards agencies as independent regulators, there are frequent complaints about either political or sectoral capture. This means that they are actually not independent from politics or large companies in the sectoral markets. In addition, as characteristic of Eastern Europe, there are constitutional concerns about them breaking the principle of division of powers in a state. Namely, independent regulators often have - beside regulatory - also supervisory and licensing competences (Koprić et al., 2012/13: 27). Furthermore, the delegation of tasks and privatization in the framework of NPM, Neo-Weberianism and good governance theories, lead to new forms of democratic accountability (Eymeri-Douzans \& Pierre, 2011: 80, 120-149).

The main argument put forward within PAR is that agencification, by delegating authority from state bodies to regulatory agencies, guarantees independence and autonomy from politics of the day and ensures higher efficiency due to professional standards. The sectoral policies in question are most often - in Slovenia and the region alike - public finances and services of general interest (e.g. market security, insurance supervision, energy, telecommunication and post, transport, food safety, education, etc.). However, due to democratic deficit in case of such "technical" agencies, control is crucial to establish their accountability. Control mechanism should range from parliamentary and governmental (representative) control to general public supervision (cf. Rose-Ackerman \& Lindseth, 2011: 516).

A theoretical and comparative literature overview shows that the development of an efficient PA in the sense of agencification is both a tool and a target by which and toward which the state can transform its PA. Such an approach can lead to good governance, combining bureaucracy and democracy toward result-based legitimacy (Eymeri-Douzans \& Pierre, 2011: 8, 109). Political (vertical) and citizens (diagonal) accountability are in consequence inevitable major elements of evaluation of agencification goals' implementation, in both functional and organizational dimensions of PA reform. In this respect, following Pollitt \& Bouckaert (2004, 2011), there are crucial differences between individual countries pursuing PAR that relate, as enlightened in this research, to structural organization of PA on the national level and the minister-to-mandarin relations.

\section{Results of the Analysis of Agencifica- tion and Agencies' Structural Autonomy in Slovenia}

\subsection{Methodology on structural and other goals and effects of agencification}

Since no study on the impact of agencies' autonomy in relation to agencification elaborated as a consistent part of PAR has been found in literature (see Chapter 2), the research in this respect was initiated in 2013 as an upgrade of previous studies carried out in the region in 2011-2012. The purpose was to gain new information and knowledge in an interdisciplinary context. The research design is based on theoretical framework, mainly following Pollitt \& Bouckaert's categorization of Neo-Weberian mode in PA. Taking into account the complexity of the field and the lack of quantitative data, the research methods applied were mainly qualitative ones, from descriptive analysis to semi-structured interviews. Selected comparative insights of agencification in (Eastern and broader) Europe were applied as much as possible as a complementary method. In terms of selecting variables, 
PAR documents represented the independent variable while the agencies' autonomy represented the dependent one. The research explored the influence of PAR elaboration of agencification on the agencies' organizational and managerial autonomy.

In empirical terms, the official Slovenian PAR documents adopted between 1996 and 2014 were analyzed first. In this part an analysis of the declaratory goals of agencification in several PAR documents (strategies and umbrella legislation) over the last two decades was carried out. Since Slovenia has been a member of the EU since 2004, the influence of the EU is discussed as well. As indicated in Table 3, all PAR strategies and umbrella legislation adopted since 1991 were included. Documents were analyzed regardless of the level of policy maker (parliament or government), left or right wing oriented issuer, or phase of elaboration (draft or adopted) - as long as they were cross-sectoral and nationally driven. Data with regard to the level of emergence and realization of agencies' dimension in PAR documents (Table 3 ) were analyzed using different scientific and comparative studies (such as Kovač \& Virant, 2011, Pevcin et al., 2012, Verhoest et al., 2012, Vintar et al., 2013, UNAID, 2013).

In order to assess the actual effects of agencification, particularly in structural dimensions compared to the ones declared in strategic documents, normative and statistical analyses were carried out among all 16 state public agencies, with additional interview-based research. Field legislation and quantitative data from the agencies' annual reports with statistics for 2011-2013 were analyzed to evaluate the organizational and managerial autonomy and efficiency of agencies.

To verify the assessments, follow-up interviews were conducted among representatives of seven public agencies and a control group of representatives of (most) corresponding ministries, covering the sectors of finances, economy, transport, science and education. Only top managers were included to offer strategic perspectives, namely directors of the agencies and state secretaries or directors general at the ministries. Such model enables further research and evidence-based decision-making in the field of agencification as a crucial PAR process at the national level and comparatively (as partially already conducted in SEE, cf. Koprić et al., 2012/13).

The interviews included questions and data gathering in relation to the agencies' autonomy from politics and, in particular, line ministries in their daily work, with special emphasis on organizational forms, HR and finance management, and professionalism. Additionally, control questions on the efficiency of agencies were asked. The said aspects (forms of autonomy, professionalism and efficiency) were emphasized as the primary goals of agencies' establishment. The data indicated in Table 5 were analyzed combining objective indicators and subjective experts' opinions on structural and partially functional autonomy (upgrading an earlier study of 2012, cf. Pevcin et al., 2012: 172). The following objective indicators were selected:
1. stability of agency in terms of tradition - longer existence, higher A-D grade (Table 5, column 3);

2. legal independence, i.e. the legally defined personality of the agency outside the line ministry - the more regulated and emphasized organizational independence in relation to the parent ministry and the government, the higher A-D grade (Table 5, columns 4 and 5);

3. statistical data on HR and finances - the less influence of the ministries on employment, the larger the size of personnel and its expertise, and more funds not only from the state budget but also from the agencies' own fees, the higher A-D grade (Table 5, columns 6 and 7).

In addition, a complementary subjective evaluation by the interviewees was required to verify the relevance of selected objective indicators (from agencies' annual reports) for final assessment.

The study is of course subject to some limitations. Although including different ministerial sectors and field agencies in interviews, the results could vary if all agencies and line ministries were covered (the interviews focused on selected agencies and corresponding ministries since they represent a legitimate majority in terms of the type, sector and number of agencies in Slovenia). Furthermore, some managers in top positions declined cooperation (being subjected to political will of new appointments in short time or similar). Finally, there had been so many changes in recent years that it would have been difficult to objectively evaluate the current situation. Given the methodology applied with due consideration of Slovenia's specifics, the results are valid within the region only. In future, a similar research could be designed and applied at least in the context of Eastern Europe. This would allow academia to gather comparable data and grasp new scientific findings to form professional recommendations for politicians on how to design better PAR.

\subsection{Analysis of the agencification process in Slovenia}

The regulation of public agencies has always been one of the key EU-driven reform programs although they have not been carried out consistently (Vintar et al., 2013: 168). The new Slovenian State Administration Act, in combination with the Public Agencies Act (PAA), both in force since 2002, revised the system of governance in state administration. Pursuant to the PAA, a public agency is an independent legal entity, founded by the state or a municipality with the purpose of more efficient execution of administrative tasks or in case when constant political supervision over task implementation is not necessary or appropriate. Public agencies act as public authority holders, issuing secondary legislation and deciding in individual administrative cases on the basis and within the scope of sectoral laws (with acts; Kovač, 2006: 180, 266 and the following). The PAA regulates the establishment of an agency, its bodies (council and director), competencies, tasks and activities, supervision, relations 
between the agency and its line ministry, relations with users, transparency standards, financing, etc.

The council consists of the members appointed by the founder and of the representatives of the users (from one third to one half). The employees in public agencies are considered civil servants, albeit only several chapters of the Civil Service Act are applicable to public agencies. Pursuant to sectoral laws, agency employees are mostly included in the common governmental personnel plan (Koprić et al., 2012/13: 19, cf. Kovač \& Virant, 2011: 150), which is a government tool for limiting the resources of the agencies, too.

The figures for Slovenia indicate one regulatory agency established in 1994 and five in 2000, 16 in 2010 and 17 in 2012 , with two less and one more in 2013. The number of employees in agencies varies significantly (from 3 to 250; total about 800 in 2013). The majority of agencies fall under the scope of the ministries of economy (five) and finance (four), some under the ministry of transport and some under non-commercial sectors of science, education, culture and health (some agencies fall under the supervision of two field ministries). There are several phases of agencification in Slovenia (Table 2), with some recent attempts toward slight de-agencification.

After 2000, the proliferation of public agencies can be observed in Slovenia as well as in the region. The processes of transition and accession to the EU led to a rapid increase in the number of agencies in CEE in order to implement new or reorganized functions of democratic state, market economy and EU member state (Hajnal et al., 2011: 160). In Slovenia, however, proliferation and then again de-agencification, characteristic of the second half of 2000s, was more moderate (cf. Musa \& Koprić, 2011: 60 and the following, for Croatia with 75 statutory agencies, and UNAID, 2013: 78, for Serbia, counting app. 30 public agencies in 2013). The process of agencification in Slovenia intensified and is still progressing, especially with regard to the aspects of (personnel and financial) autonomy. In 2011, the Govern- ment designed an explicit reform program regarding public agencies, institutions and funds as part of the general PAR. The analysis and measures to be taken according to the 2011 draft strategy were in accordance with theoretical, comparative and practical recommendations, especially the differentiation of public agencies into regulatory and general ones, the rationalization of organization, and program budgeting. In sum, the emergence of public agencies puts Slovenia compared to global trends - within the ratio of 2:1 between executive and independent public agencies (cf. regional ratios in Verhoest et al., 2012: 20)

\subsection{Agencies within PAR in Slovenia - declarative dimensions}

A thorough analysis of the key strategic documents on PAR in Slovenia was carried out to study the goals and measures of reforms involving agencification and type 2 public agencies. However, these documents differ considerably in terms of scope, main objective/s and level of details. In addition to contextual and methodological differences, there are also obvious differences with regard to the question whether, how and to what extent PAR addresses the agencies (Table 3, cf. Vintar et al., 2013: 164). Based on theoretical and comparative knowledge on agencification as a crucial and inevitable part of PAR, such analysis offers an insight into political coherence and professional grounds of agencification or the lack thereof.

As for the agencification goals in Slovenian PAR strategic documents, mainly two (groups of) issues can be identified on declaratory or operational levels (Table 3):

1. Strive for apolitical and professional conduct of expertise-driven public tasks;

2. Efforts to rationalize PA and public expenditure as a whole, in absolute spending and more efficient working processes.

Table 2: No. of (public) agencies in Slovenia (type 2, national level) over time (source: own analysis)

\begin{tabular}{|c|c|c|}
\hline Years & No. of new agencies & In sum \\
\hline$-2000(1994-)$ & 1 & 1 \\
\hline $2000-2004$ & 7 & 8 \\
\hline $2005-2008$ & 3 & 11 \\
\hline $2009-2012$ & 6 & 17 \\
\hline $2012-2014$ & -2 (1 new, 1 abolished, 2 merged) & $\mathbf{1 6}$ \\
\hline
\end{tabular}


Table 3: Overall strategic documents on Slovenian administrative reforms (Sources: Kovač \& Virant, 2011, Vintar et al., 2013, etc. \& own descriptive analysis)

\begin{tabular}{|c|c|c|c|c|}
\hline Strategy (adopted) & $\begin{array}{l}\text { Year of adoption } \\
\quad \& \text { issuer }\end{array}$ & Period & Agencies'elements & $\begin{array}{l}\text { Realization in } \\
2014\end{array}$ \\
\hline Strategy for EU Accession & $\begin{array}{l}\quad 1996 \\
\text { Parliament (left- } \\
\text { wing driven, but } \\
\text { overall political } \\
\text { consensus) }\end{array}$ & 1997-99 & $\begin{array}{c}\text { Agencies foreseen } \\
\text { systematically as a key holder } \\
\text { of EU driven regulatory and in } \\
\text { some cases executive tasks as } \\
\text { set by special law }\end{array}$ & Mainly \\
\hline $\begin{array}{c}\text { Umbrella laws } \\
\text { (State PA, Agencies, } \\
\text { Inspection, Wages, Civil } \\
\text { Service, etc.) }\end{array}$ & $\begin{array}{c}2002 \\
\text { Parliament } \\
\text { (left wing-driven, } \\
\text { but overall political } \\
\text { consensus) }\end{array}$ & $2000-03$ & $\begin{array}{c}\text { Special umbrella law on } \\
\text { (public) agencies, in compliance } \\
\text { with systemic forms set by State } \\
\text { Adm. Act, Civil Service Act, } \\
\text { etc. }\end{array}$ & $\begin{array}{l}\text { Almost fully in } \\
\text { structural, less in } \\
\text { functional parts }\end{array}$ \\
\hline $\begin{array}{l}\text { Strategy on Further } \\
\text { Development of the } \\
\text { Slovenian Public Sector }\end{array}$ & $\begin{array}{l}2003 \\
\text { Government (left) }\end{array}$ & $\begin{array}{l}\text { (incl. 2000-) } \\
\text { 2003-05 }\end{array}$ & $\begin{array}{l}\text { Pursuing implementation of key } \\
\text { umbrella laws, incl. on agencies }\end{array}$ & $\begin{array}{l}\text { Mainly, again } \\
\text { prevailing in } \\
\text { structural aspects }\end{array}$ \\
\hline $\begin{array}{c}\text { Slovenia's Development } \\
\text { Strategy }\end{array}$ & $\begin{array}{l}2004 \\
\text { Governments } \\
\text { (left \& right) }\end{array}$ & 2005-13 & $\begin{array}{l}\text { Agencies part of "efficient } \\
\text { state" goals/activities, } \\
\text { emphasized further need for } \\
\text { agencies when PAA criteria } \\
\text { met, role of control agencies } \\
\text { and enhanced coordination }\end{array}$ & $\begin{array}{l}\text { Partly and rather } \\
\text { declaratory }\end{array}$ \\
\hline $\begin{array}{l}\text { Exit (from economic } \\
\text { crisis) Strategy }\end{array}$ & $\begin{array}{l}2010 \\
\text { Government (left) }\end{array}$ & $2010-13$ & $\begin{array}{l}\text { Focus on increasing efficiency } \\
\text { in reducing state budget burden }\end{array}$ & $\begin{array}{l}\text { Partly, and purely } \\
\text { in individual } \\
\text { agencies }\end{array}$ \\
\hline $\begin{array}{l}\text { *Draft - The Origins of } \\
\text { Further Development } \\
\text { and Organizational and } \\
\text { Normative Regulation of } \\
\text { the Public Sector }\end{array}$ & $\begin{array}{c}2011 \\
\text { Government }\end{array}$ & $2011-12$ & $\begin{array}{l}\text { Detailed general and individual } \\
\text { measures on agencies within PA } \\
\text { as a whole }\end{array}$ & $\begin{array}{l}\text { Partly, as pursued } \\
\text { prior and parallel } \\
\text { to this document }\end{array}$ \\
\hline $\begin{array}{l}\text { Changed jurisdiction of } \\
\text { ministries, agencies and } \\
\text { funds } \\
\text { \& State Adm. Act } \\
\text { amendment }\end{array}$ & $\begin{array}{l}2012 \text { Government } \\
\text { \& Parliament (right } \\
\text { wing majority) }\end{array}$ & $2012-$ & $\begin{array}{l}\text { Overall understanding of PA } \\
\text { as a system, besides ministries } \\
\text { and entities within them also } \\
\text { public agencies (and funds } \\
\text { and institutes), but only } \\
\text { organizational restructuring }\end{array}$ & $\begin{array}{l}\text { Partly (new } \\
\text { government in } \\
\text { power after few } \\
\text { months) }\end{array}$ \\
\hline $\begin{array}{l}\text { Origins for further PA } \\
\text { development }\end{array}$ & Government (left) & $2014-20$ & $\begin{array}{c}\text { None, only some points on } \\
\text { efficiency of PA in general } \\
\text { and on heterogeneous PA } \\
\text { organizations }\end{array}$ & $/(!)$ \\
\hline
\end{tabular}


The two main goals - (1) professional, organizational and managerial autonomy and (2) efficiency - are stated in most strategic and supporting documents as well as in laws (State Administration Act, Art. 15, or PAA, Art. 4 and sectoral legislation). However, professionalization prevails in the first decade (mid-90's to 2004) and efficiency afterwards, particular after 2010. Nevertheless, despite coherent upgrading and an obvious implementation gap, there is in sum great analogy between the normative objectives of Slovenian strategies and legislation and the model of professional and managerial autonomy set by OECD (2002, see Table 4).

As indicated in Table 4, in certain elements Slovenian agencies seem to exceed the standardized autonomy required by OECD if one did not simultaneously identify (see the following sections) the implementation gap (cf. Polidano, 1999: 210, Virant \& Kovač, 2011: 71-73, Pevcin et al., 2012: 166). The strategic and regulatory framework is therefore an important - yet, following comparative experiences, only one - element of agencification.

\subsection{Agencification - implementation gaps in structure and functions}

Coordination and policy coherence gaps may, in general and in transitional countries in particular, raise the question of political accountability, provoke robust political interventions, and undermine the level of autonomy and expertise, especially where a firm legal framework does not limit the influence of politics (Koprić et al., 2012/13: 40, cf. Laking, 2005: 8, 17). In consequence, the recent proliferation of agencies in those countries causes many new and enhances old problems of PA (cf. Verhoest et al., 2012: 23, UNAID, 2013: 5 and the following).

The biggest problem in the Slovenian agencification process and agencies' conduct, as indicated by the managers of some of the agencies involved in the research, is the lack of vision as to which public tasks should be delegated to autonomous agencies. Even the Europeanization process impact has been evident in sectoral legislation only. The insufficient expertise and formalistic approach of agencies and their parent ministries was accentuated by the interviewees in several aspects. Such a situation is partially a consequence of the transitional heritage, i.e. of the lack of professional public management and well-designed public policies (cf. the same for other EE countries in Koprić et al., 2012/13, UNAID 2013). However, all interviewees find expertise and professionalism to be the key bases of true agency autonomy, allowing them to act apolitically.

Hence rather surprisingly, empirical research proves that legal aspects are an important but insufficient condition to achieve the desired independence and political neutrality in praxis (cf. Koprić et al., 2012/13: 29). As stated in one interview: "The guarantees of independence of agencies in the PAA are rather formal" and lacking "independence guarantees". Two major problems arise according to the in- terviewees from both agencies and ministries. Firstly, there are non-systematic differences in the autonomy level in various types of organization. In fact, lower independence is detected in the entities that legally should be autonomous. The autonomy thereof is otherwise guaranteed in several aspects: organizational, legal, functional, procedural, financial, and in terms of personnel (Kovač \& Virant, 2011: 70-73, Bugarič, 2004: 1394-1402). Secondly, there is a discrepancy between autonomy and responsibility. Furthermore, it was argued that there should be a clear distinction between regulatory agencies and other agencies connected to the ministries (cf. Government, 2011).

In order to get more tangible results, the level of autonomy in different theoretically recognized dimensions (organizational, legal, managerial, financial) was evaluated from A to D (A as the highest autonomy, see more in 3.1). All Slovenian public agencies operating in 2014 were examined. The results are indicated in Table 5.

The main criteria of autonomy were set based on the third research question, exploring the gap between declared goals - i.e. professional autonomy to enable efficiency - and the actual effects of agencification in this respect.

In sum, there is an evident gap between declared and actual autonomy and independence as defined in theory and field legislation with (say) A/B in the long run. However, the situation as such is not necessarily problematic as long as the most important aspects of autonomy comply with the goals set in strategies and laws. However, this is not the case since professional and managerial autonomy (i.e. the most crucial ones) are evaluated as the lowest. On the contrary, particularly legal aspects are quite fully realized, which is characteristic of post socialist countries following formal rather than substantive elements of reforms (cf. Dunn et al., 2006, Eymeri-Douzans \& Pierre, 2011: 24, 184, Verhoest et al., 2012: 55). According to the interviewees from Slovenian parent ministries and agencies, there is a large implementation gap between the goals set in strategic PAR documents and umbrella legislation and real practices. Nevertheless, the following conclusion can be drawn: professionalism-based independence and autonomy (with anticipated improved efficiency) of the respective agencies are the goals to be researched and pursued further within systemic PAR.

\section{Discussion}

Gradually but distinctively, agencies have been introduced as an organizational form worldwide in order to develop, in particular, independent regulators and leaner execution of public services. The prevailing goal declared in strategic Slovenian documents and draft laws of the founding (new) public agencies was initially PAR. Such goal was set in 1996 to divide strategic policy-making from implementation (steering from rowing, see Schick in OECD, 2002: 41). The development of (type 2) agencies' autonomy was further grounded in Slovenia in the effort to achieve political neutrality and professionally-driven implementation of 
Table 4: Agencification goals according to OECD and Slovenian PAR documents (source: Kovač \& Virant, 2011: 69 \& own analysis of PAR documents from Table 3, based on OECD, 2002: 15)

\begin{tabular}{|c|c|c|c|c|}
\hline \multicolumn{2}{|c|}{ Agencification driving forces/goals } & $\begin{array}{c}\text { OECD - } \\
\text { governance, } \\
\text { environment }\end{array}$ & $\begin{array}{c}\text { OECD - } \\
\text { managerial \& } \\
\text { expertise autonomy }\end{array}$ & $\begin{array}{c}\text { Slovenian } \\
\text { PAR acts } \\
\text { /imple- } \\
\text { mented? }\end{array}$ \\
\hline \multirow[t]{4}{*}{$\begin{array}{c}1 . \\
\text { Expert \& } \\
\text { managerial } \\
\text { autonomy }\end{array}$} & a. Independence & recommended & requested/ no & $\begin{array}{l}\text { requested/ } \\
\text { different, } \\
\text { possible }\end{array}$ \\
\hline & b. Continuity & possible & requested/ possible & $\begin{array}{l}\text { possible/ } \\
\text { often }\end{array}$ \\
\hline & c. Participation of civil society & possible & requested/ possible & $\begin{array}{l}\text { possible/ } \\
\text { low }\end{array}$ \\
\hline & $\begin{array}{l}\text { d. Participation of users, } \\
\text { partnerships }\end{array}$ & possible & requested/ possible & $\begin{array}{l}\text { requested/ } \\
\text { moderate }\end{array}$ \\
\hline \multirow[t]{3}{*}{ 2. Efficiency } & $\begin{array}{l}\text { a. Specialization, user } \\
\text { orientation }\end{array}$ & requested & tpossible & $\begin{array}{l}\text { requested/ } \\
\text { moderate }\end{array}$ \\
\hline & $\begin{array}{l}\text { b. Managerial methods, } \\
\text { management by results }\end{array}$ & requested & possible & $\begin{array}{l}\text { requested/ } \\
\text { low }\end{array}$ \\
\hline & $\begin{array}{l}\text { c. Loosened admin. \& financial } \\
\text { rules }\end{array}$ & possible & possible/ requested & $\begin{array}{c}\text { requested/ } \\
\text { moderate only }\end{array}$ \\
\hline
\end{tabular}

delegated public tasks (Kovač, 2006: 260 and the following). The relative independence from daily politics and short-term interests of the parties in power when carrying out regulatory and other agencies' functions was the goal intended to lead to higher efficiency of PA at the end of the day.

In Slovenia, type 2 public agencies were created largely from the already existing bodies within ministries (as next steps agencies, cf. Verhoest, 2012: 21). However, this process was not systematically conducted, since there are still a large number of executive (internal, semi-autonomous) agencies within the ministries (about 35 in 2014). Later on, partial measures were taken, from redefining parts of state administration as - at least with regard to their legal status - autonomous agencies on one hand, to merging several autonomous agencies into ministries in 2011 and 2012 on the other. There has been no functional analysis whatsoever of overlapping tasks or effects of agencification. It seems, at least in most areas, that restructuring is occurring outside the administration mainly to avoid the restrictive governmental policy on expenditure (cf. Vintar et al., 2013: 163, cf. the same for Croatia in Musa \& Koprić, 2011: 68).

The proliferation of agencies in Slovenia was in such context a result of several typical factors, such as NPM - as opposed to traditional Weberian PA - favoring the separation of policy making from execution. Additionally, agencification is in place to deal with an increasing complexity of public tasks calling for the establishment of expert forms of PA organizations. Obviously some agencies were driven by the process of the country becoming a full EU member. As indicated in Table 2, most agencies were established in the region during the Europeanization process, taking place in Slovenia around 2004. The idea of independent administrative institutions was closely linked to the privatization of (economic) public services to ensure coordination between general public and private interests.

But here the state still seeks for stabilization and professionalism of agencies as opposed to transitional politicization, considering that some agencies established in 2008 are now being abolished based on what is known as the 2012 government rationalization program (see Koprić et al., 2012/13: 39-41). One can claim the classical Weberian bureaucratic model to be outdated today, but some of its dimensions are still relevant (more in Pollitt \& Bouckaert, 2011) - especially in developing a coherent PA system by decentralization and delegation to agencies. The neo-Weberian paradigm therefore serves as a basis for bureaucratic competency and for the stability and control of the state (Randma-Liiv, 2008: 12, cf. Pollitt \& Bouckaert, 2004: 99-100).

In striving to overcome the system's dissonances with regard to agencies, the problem appears to be other than the law or the inconsistent strategies themselves. 
Table 5: Analysis of national public agencies'autonomy (source: own research)

\begin{tabular}{|c|c|c|c|c|c|c|c|}
\hline No & $\begin{array}{c}\text { Agency and parent } \\
\text { ministry }\end{array}$ & Since & $\begin{array}{l}\text { Status/ } \\
\text { org. }\end{array}$ & $\begin{array}{l}\text { Legal } \\
\text { views }\end{array}$ & HRM & Finances & $\begin{array}{c}\text { Overall } \\
\text { autonomy }\end{array}$ \\
\hline 1 & $\begin{array}{l}\text { Security Market }\left(\mathrm{ATVP}^{*}\right) / \\
\text { finances }\end{array}$ & $\begin{array}{c}\text { A } \\
1994\end{array}$ & A & A & $\mathrm{C}$ & A & $\mathbf{A}$ \\
\hline 2 & $\begin{array}{l}\text { Insurance Supervision } \\
(\mathrm{AZN}) / \text { finances }\end{array}$ & $\begin{array}{c}\text { A } \\
2000\end{array}$ & A & A & B & A & $\mathbf{A}$ \\
\hline 3 & $\begin{array}{c}\text { Energy (AGEN-RS) / } \\
\text { economy }\end{array}$ & $\begin{array}{c}\text { A } \\
2001\end{array}$ & A & B & $\mathrm{C}$ & B & B \\
\hline 4 & $\begin{array}{l}\text { Telecommunica-tion, post } \\
\text { (AKOS) / economy }\end{array}$ & $\begin{array}{c}\text { A } \\
2001\end{array}$ & A & B & $\mathrm{C}$ & $\mathrm{C}$ & B \\
\hline 5 & $\begin{array}{l}\text { Public Records (AJPES) / } \\
\text { finances }\end{array}$ & $\begin{array}{c}\mathrm{A} \\
2002\end{array}$ & B & A & $\mathrm{C}$ & $\mathrm{C}$ & B \\
\hline 6 & Research (ARRS) / science & $\begin{array}{c}\text { A } \\
2003\end{array}$ & B & A & A & $\mathrm{C}$ & $\mathbf{B}$ \\
\hline 7 & Railway (AŽP) / transport & $\begin{array}{c}\mathrm{A} \\
2003\end{array}$ & B & $\mathrm{C}$ & A & B & B \\
\hline 8 & $\begin{array}{l}\text { Entrepreneurship, tourism, } \\
\text { innovation, investment } \\
\text { (SPIRIT) / economy }\end{array}$ & $\begin{array}{c}\mathrm{B} \\
2004 / 5 / \\
2012 \\
\end{array}$ & B & $\mathrm{C}$ & B & $\mathrm{C}$ & B \\
\hline 9 & Medicines (JAZMP) / health & $\begin{array}{c}\mathrm{B} \\
2006\end{array}$ & B & $\mathrm{C}$ & $\mathrm{C}$ & B & B \\
\hline 10 & $\begin{array}{c}\text { Books (JAK) / culture, } \\
\text { science }\end{array}$ & $\begin{array}{c}\mathrm{B} \\
2008\end{array}$ & B & $\mathrm{C}$ & $\mathrm{C}$ & $\mathrm{C}$ & $\mathrm{C}$ \\
\hline 11 & $\begin{array}{l}\text { Public Revision (ANR) / } \\
\text { finances }\end{array}$ & $\begin{array}{c}\mathrm{C} \\
2009\end{array}$ & A & B & $\mathrm{C}$ & $\mathrm{C}$ & $\mathrm{C}$ \\
\hline 12 & $\begin{array}{c}\text { High Education } \\
\text { Quality (NAKVIS) / } \\
\text { education } \\
\end{array}$ & $\begin{array}{c}C \\
2009\end{array}$ & $\mathrm{~B} / \mathrm{C}$ & $\mathrm{C}$ & A & $\mathrm{C}$ & C \\
\hline 13 & $\begin{array}{c}\text { Traffic Security (AVP) / } \\
\text { transport }\end{array}$ & $\begin{array}{c}\mathrm{C} \\
2010\end{array}$ & B & $\mathrm{D}$ & $\mathrm{C}$ & $\mathrm{C}$ & $\mathbf{C}$ \\
\hline 14 & $\begin{array}{c}\text { Civil Aviation (CAA) / } \\
\text { transport }\end{array}$ & $\begin{array}{c}\mathrm{C} \\
2010\end{array}$ & B & $\mathrm{C}$ & $\mathrm{C}$ & $\mathrm{C}$ & $\mathrm{C}$ \\
\hline 15 & Film Centre (SFC) / culture & $\begin{array}{c}\mathrm{C} \\
2011 \\
\end{array}$ & B & $\mathrm{C}$ & $\mathrm{C}$ & $\mathrm{C}$ & $\mathrm{C}$ \\
\hline \multirow[t]{2}{*}{16} & $\begin{array}{l}\text { Competition Protection } \\
\text { (JAVK) / economy }\end{array}$ & $\begin{array}{c}\mathrm{D} \\
2013\end{array}$ & A & A & A & $\mathrm{C}$ & B \\
\hline & Sum/Average & B- & A- & B- & $\mathrm{C}+$ & C- & $\mathrm{B} / \mathrm{C}$ \\
\hline
\end{tabular}


The key issue is the difficulty to redefine administrative (sub) function and structures in order to ensure proper implementation of the law or strategy. Moreover, several reform processes in Slovenia were a mere "window-dressing" copy of the Western patterns (more for Slovenia in Vintar et al., 2013: 152). Decision makers used them as a shortcut to achieve the (idealistic) level of economic and democratic progress opposed to the historical experience of these countries in the past 50 years. Consequently, some of the reforms were rejected in the implementation phase for not being in compliance with the Slovenian societal and administrative framework and culture.

On the other hand, one cannot deny the positive effects of PAR and agencification in EE, included merely for the sake of hitherto deficiencies. On the contrary, in EE as in Western Europe, the agency model of PA seems to be a future parallel system to state administration when downsizing the latter in circumstances of financial crisis (Vintar et al., 2013: 153, cf. rather vice versa experience in CEE in general in Hajnal, 2011: 164). However, as assumed at the beginning of the study, (more) systematic PAR elaboration with regard to agencification is in place in EE and Slovenia alike.

One of the key problems seems to be the lack of a systematic approach to agencification owing to non-coordinated governmental field policies. This is proven by various other methods, from analysis of PAR documents to academia evaluation of PAR results and interviewees' experience. Such is evident (in Slovenia) especially in agencies under the auspices of two parent ministries. The reason for that could be the legacy of post-socialism with only partially executed transition processes, hence lower level of democratization within the society in general (cf. Verhoest et al., 2012: 335). Comparatively, it can be concluded that the trajectory of agencification in CEE countries differs from the trajectory in Western European countries in several aspects, mainly with regard to agencies' proliferation, less variation in types of agencies (with the predominance of the less autonomous type 1 agency), and unstable situation due to recent processes in place (Van Thiel, 2011: 16-29, cf. Koprić et al., 2012/13: 40-41).

What raises particular concern in EE, however, is that certain governments refuse the measures designed by their differently oriented predecessors just for the sake of anti-stance or in total lack of awareness of the importance of agencification (as if ignoring the problem would resolve it), which has become particularly evident in the recent two to three years. Focusing on efficiency alone is particularly risky since several interdependent functional and structural goals of agencification are to be interlinked (cf. Government, 2010, 2012; Verhoest et al., 2012: 413). In this context, the governmental draft strategy of 2011 (as declared in the internal materials of over $200 \mathrm{pp}$.) stands out as a rare positive exception.

This strategy, which was not adopted due to early parliamentary elections, stated clear aims regarding agencies. It combined the rationalization of resources with democrat- ic governance based on autonomy and professionalism. In more detail: the strategy set the goal of rationalization in the field of (public) agencies by at least $10 \%$ of management expenditure on the basis of improved performance and acquisition of market resources (up to 50\%). Moreover, (public) agencies would be differentiated in terms of autonomy and appropriate resources maintained for independent regulators, while pure executive agencies would be transferred to ministries or contracted out (cf. Laking, 2005: 10-12, Kovač, 2006: 59, Bevir et al., 2011: 287).

Basically, the key measure seemed to be "program driven budgeting" according to the tasks of agencies instead of their status and organizational form (cf. Verhoest, et al., 2012: 340). Quite the opposite, several counterproductive measures led to decreased autonomy and efficiency in respective fields. Examples range from founding an agency only to abolish it a year after (e.g. the Public Procurement Agency), merging incompatible tasks and types of procedures within the same agency (such as entrepreneurship subsidies distribution and tourism development within SPIRIT), or redefining present agencies and funds only to reduce the number of delegated tasks holders (e.g. the planned merger of Medicines Agency, Institute of Public Health etc., see Government, 2012). Some scholars point out that frequent reorganization leads to lack of agencies' accountability, since the role of agencies' managers is increased beyond ministerial control (Lane, 1995: 188, Christensen \& Lægreid, 2006: 133). However, also the side effects - such as technocracy - have to be identified to be overcome (see Koprić et al., 2012/13: 26, 41).

To conclude, a coherent strategic approach to agencification in general and in individual fields is required in order to strive for the basic goals of professional delivery of public tasks. An efficient administrative system is however achieved not only by input-output economy lenses but holistically, based on the attainment of public policies' goals and preservation of public interest (Lane, 1995: 3, Verhoest et al., 2012: 432).

How to control the agencies (steering) while at the same time leaving them a significant degree of autonomy for the apolitical and more efficient performance of their tasks is the key question of the agency model. This question arises in particular in type 2 i.e. autonomous (external) agencies outside ministries (see Christensen \& Lægreid, 2006, 2011; and Verhoest et al., 2012). The agencies' autonomy is relative and can be intensified or reduced, but must not eventually annul the impact of democratically elected authorities and users. Otherwise, the principles of the rule of law and social state, and common (public) interest are affected.

Not surprisingly, good governance practice, which would replace direct politicization as a steering mechanism (reporting, performance management, appointments, coordination, transparency), is still in the nascent state in the region (Hajnal et al., 2011: 172, Koprić et al., 2012/13: 41, Vintar et al., 2013: 126). 
Finally, to analyze PAR in terms of agencification, an interdisciplinary approach (cf. Raadschelders, 2011: 181, Peters \& Pierre, 2005: 265) is of key importance. In complex social situations narrower measures are not sufficient to tackle wicked problems. PA is always a professional and indispensably holistic process, more than just auxiliary in its operations, enabling the running of the basic public policies adopted by others. PA is a social subsystem and a pillar of the administrative level of public governance in the sense of the implementation of institutional public policies (cf. Raadschelders, 2011: 12-41). PA is therefore not only a productive activity but necessarily a creative one (Kovač \& Virant, 2011: 30). It contributes to the overall progress of society since its main characteristics include constancy, a systematic nature, and initiative.

One of the above wicked problems is the current economic crisis, strongly influencing the agencies' resources and eventually even their existence. Several interviewees stated that in this respect there was a possibility of capture problem, since Slovenia is a small state with a limited number of field experts, many of them with previous experience and expertise in the regulated market. Because of that, some former directors of the companies operating in the respective fields become members of the agencies' councils. Thus, they frequently act as representatives of particular interests rather than of public interest. Interviewees also reported that there was a need to exclude agency employees from the civil service and from the unified public remuneration system (cf. the same already by OECD, 2002, or Pollitt \& Talbot, 2004). However, to introduce such measures, evidence-based analyses should first be conducted in order to enable precise and targeted action. An integrated subject of study and a combination of research methods that builds on the content and approaches of the disciplines that make up PA is of utmost support and necessity in these researches.

\section{Conclusion}

The modern state and its PA are supposed to ensure a democratic and sustainable development and an efficient delivery of public tasks. In this context, agencies represent the sum of the efforts toward an expertise-driven and efficient PAR, in both national and supranational frameworks. Hence, agencification as a process and a form of public organization is an inevitable part of modern PA. However, policy makers are to be held accountable for public policies' design and implementation, which requires a necessary review and evaluation of PAR measures and the effects thereof.

The answers to the research questions elaborated for the purpose of this study are the following. Firstly, in Slovenia there are several PAR strategies or umbrella laws adopted in the last two decades, addressing public agencies and their role in PA, but the notion of agencies is not coherent. Moreover, there is no evaluation model designed to review the implementation of agencification activities within PAR documents. Secondly, almost all PAR documents set basic goals as acknowledged in theory and comparative analyses. Sometimes these goals are found under other titles but basically it is about enhancing organizational and managerial autonomy of public agencies in order to deliver public tasks more professionally and efficiently. The process of agencification in Slovenia was, owing to Europeanization in 2000-2004 and the efforts to overcome the economic crisis in place since 2008 , rather intensive. The goals of agencification mainly included expertise as opposed to politically-driven, and efficacy-oriented public tasks implementation. At such declaratory levels, it can be concluded that Slovenian efforts comply with professionalism and efficiency pursued worldwide.

However, when evaluating the effect of implementation as analyzed under the third research question, an obvious gap can be detected. Namely, the structural changes achieved can only partially support the desired improvements. A functional renewal of PA is hence required, such as programming sectoral public policies and, accordingly, their funding. Structural elements, on the other hand, such as legal personality of public agencies and the still preserved control by the ministries, have their limits, as noted by the interviewees. This is a problem since further policies addressing complex societal (wicked) problems in the scope of PA have to be evidence-based if indeed optimal in the long run. One can only hope that, when searching for best practices abroad, Slovenia will follow such systematic approach in this cross-sectoral field.

\section{Literature}

Bevir, M. (Ed.) (2011). The SAGE Handbook of Governance. Los Angeles: Sage.

Boston, J. (2011). Basic NPM ideas and their development. In Christensen, T., \& Lægreid, P. (Eds.), New Public Management (17-32). Farnham: Ashgate.

Bugarič, B. (2004). O prenosu pristojnosti z države na paradržavne in nedržavne organizacije: »razdržavljanje» države? [About delegation from state to para-state and non-state organizations: "dis-stating" the state?]. Podjetje in delo, XXX(6-7), 1394-1402.

Christensen, T., \& Lægreid, P. (Eds). (2006). Autonomy and Regulation. Coping with Agencies in the Modern State. Cheltenham: Northampton, MA: Elgar.

Christensen, T., \& Lægreid, P. (2011). Beyond NPM? Some Development Features. In Christensen, T., \& Lægreid, P. (Eds.), New Public Management (391-403). Farnham: Ashgate.

Dunn, N.W., Staronova, K., \& Pushkarev, S. (Eds). (2006). Implementation - the Missing Link in Public Administration Reform in Central and Eastern Europe. Bratislava: NISPAcee.

Eymeri-Douzans, J.-M., \& Pierre, J. (Eds). (2011). Administrative Reforms and Democratic Governance. London, New York: Routledge.

Hajnal, G., Nakrošis, V., \& Randma-Liiv, T. (2011). Public sector organization in Central and Eastern Europe: 
from agencification to de-agencification. Transylvanian Review of Administrative Sciences, Special Issue (November 2011), 160-175.

Government \& National Assembly of the Republic of Slovenia. (1996). Strategy for Slovenia's Accession to the EU. Ljubljana: National Assembly Reporter, No. 48/97 and 48/I/97.

Government of the Republic of Slovenia. (2003). Strategy of Further Development of the Slovenian Public Sector 2003-2005. Ljubljana: Government of the RS.

Government of the Republic of Slovenia. (2005). Slovenia's Development Strategy. Retrieved September 1, 2014, from http://www.umar.gov.si/fileadmin/user_upload/ projekti/02_StrategijarazvojaSlovenije.pdf

Government of the Republic of Slovenia. (2010). Exit Strategy 2010-2013. Retrieved August 5, 2014, from http://www. arhiv.svrez.gov.si/si/teme in projekti/izhod_iz_krize/ slovenska izhodna strategija 20102013/

Government of the Republic of Slovenia. (2011). Izhodišča za nadaljnji razvoj in organizacijsko ter normativno urejanje javnega sektorja [Origins offurther development and organizational and normative regulation of the public sector]. Internal unpublished material (July 2011).

Government of the Republic of Slovenia. (2012). Pregled sprememb pristojnosti ministrstev in predlog organiziranosti ministrstev, organov $v$ sestavi, vladnih služb, javnih agencij in javnih skladov po posameznih ministrstvih [Overview and suggestions of changed jurisdiction of ministries, agencies and funds]. Internal material, appendix of State Administration Act amendment (February 2013).

Government of the Republic of Slovenia. (2014). Izhodišča za pripravo Strategije nadaljnjega razvoja slovenske javne uprave 2014-2020 [Origins for further $P A$ development 2014-2020], No. 01000-2/2014/6. Ljubljana: Government of the RS.

Koprić, I. (2013). Managing Public Affairs in South Eastern Europe: Muddled Governance. In A. M. Bissessar (Ed.), Governance: Is it for everyone? Hauppauge: Nova Science Publisher.

Koprić, I., Kovač, P., \& Musa, A. (2012/13). Agencies in three South Eastern European countries: politics, expertise and law Agencies between expertise, politics and law: the case of countries in transition in South Eastern Europe. The NISPAcee journal of public administration and policy, 5 (2), 17-44.

Kovač, P. (2006). Pravni in sociološki vidiki javnih pooblastil $v$ Sloveniji [Legal and sociological aspects if public authorities in Slovenia]. Ljubljana: University of Ljubljana, Faculty of Administration.

Kovač, P., \& Virant, G. (Eds). (2011). Razvoj slovenske javne uprave 1991-2011 [Development of Slovenian Public Administration 1991-2011]. Ljubljana: Uradni list.

Kovač, P., Rakar I., \& Remic, M. (2012). Upravno-procesne dileme pri rabi ZUP 2 [Administrative-procedural dilemmas in use of the APA, 2]. Ljubljana: Uradni list.
Laking, R. (2005). Agencies: Their Benefits and Risks. OECD Journal on Budgeting, 4(4), 7-25. Retrieved August 3, 2014, from http://www.oecd.org/ dataoecd/3/7/43487848.pdf

Lane, J. E. (1995). The Public Sector. London, Thousand Oaks, New Delhi: Sage.

Musa, A., \& Koprić, I. (2011). What Kind of Agencification in Croatia? Trends and Future Directions. Transylvanian Review of Administrative Sciences, Special Issue (November 2011), 33-53.

OECD. (2002). Distributed Public Governance. Agencies, Authorities and Other Government Bodies. Paris: OECD.

Peters, B.G., \& Pierre, J. (Eds). (2005). Handbook of Public Administration. London: Sage.

Pirnat, R. (2000). Nekatera vprašanja postopkov neodvisnih upravnih agencij [Some issues of procedures in independent administrative agencies]. Podjetje in delo, XXVI(6/7), 1393-1402.

Pollitt, C. \& Bouckaert, G. (2011). Public management reform. A comparative analysis. New Public Management, Governance and the New Weberian State (3rd edition). Oxford: Oxford University Press.

Randma-Liiv, T. (2008). New Public Management versus Neo-Weberian State in Central and Eastern Europe. Paper presented at the Trans-European Dialogue (TED) 1, Towards the Neo-Weberian State? Europe and Beyond, January 31 - February 1, 2008, Tallinn.

Pevcin, P., \& Setnikar-Cankar, S. (Eds). (2012). Razumen in razumljen javni sektor $v$ Sloveniji [Reasonable and understood public sector in Slovenia]. Ljubljana: Faculty of Administration.

Pollitt, C., Bouckaert, G. Randma-Liiv, T., \& Drechsler, W. (Eds). (2008/09). The NISPAcee Journal of Public Administration and Policy. Special Issue: A Distinctive European Model? The Neo-Weberian State 1(2).

Pollitt, C., \& Talbot, C. (Eds). (2004). Unbundled Government, A critical analysis of the global trend to agencies, quangos and contractualization. London, New York: Routledge.

Polidano, C. (1999). The Bureaucrat Who Fell Under a Bus: Ministerial Responsibility, Executive Agencies and the Derek Lewis Affair in Britain. An International Journal of Policy and Administration, 12(2), 201-229, http:// dx.doi.org/10.1111/0952-1895.981999098

Raadschelders, J. C. N. (2011). Public Administration. Interdisciplinary Study of Government. Oxford: Oxford University Press.

Rose-Ackerman, S. \& P. L. Lindseth (Eds). (2011). Comparative Administrative Law. Cheltenham, Northampton: Elgar.

UNAID. (2013). Agencies in Serbia. Analysis and Recommendations for Reform. Retrieved July 31, 2014, from http://www.bep.rs/documents/news/Analysis $\% 20$ of $\% 20$ agencies $\% 20 \mathrm{in} \% 20$ Serbia.pdf 
Van Thiel, S. (2011). Comparing agencification in Central Eastern European and Western European countries: fundamentally alike in unimportant aspects? What Kind of Agencification in Croatia? Trends and Future Directions. Transylvanian Review of Administrative Sciences, Special Issue (November 2011), 15-32.

Verhoest, K., van Thiel, S., Bouckaert, G., \& Lægreid, P. (Eds). (2012). Government Agencies: Practices and Lessons from 30 Countries. Basingstoke: Palgrave Macmillan.

Verhoest, K., van Thiel, S., Bouckaert, G., \& Lægreid, P. (2011). Governing Public Agencies in the 21st Century. Leuven: Catholic University of Leuven, Public Management Institute.

Vintar, M., Rosenbaum, A., Jenei, G., \& Drechsler, W. (Eds). (2013). The past, present and the future of public administration in Central and Eastern Europe.

Bratislava: NISPAcee Press.
Polonca Kovač completed her PhD studies on public authorities' delegation at the Faculty of Law, University of Ljubljana, in 2006. She was first employed at the Ministry of the Interior and the Kranj Administrative Unit. Since 2001, she has been working as researcher and lecturer at the Faculty of Administration in Ljubljana and was appointed Associate Professor in 2013. She is specialized in the fields of administrative law and public administration reforms. She is the (co)author of numerous scientific articles and conference papers and several monographs. She is a member of the program research group appointed by the Slovenian Research Agency for 2009-2014 on the efficiency of public sector. She is active in many national and supranational committees and networks (such as European Group of PA), and an OECD and EU expert on organization and functions of PA. 